\title{
THE EXPERIMENTAL SUBSTANTIATION OF EXCIMERIC LASER USE IN DERMATOLOGY
} V.G. KOLYADENKO, G.F. LOBANOV, S.V. DEMETSKY and N.G. ZUBRILIN

The Kiev Medical Institute, Chair of Dermatology 13, Shevchenko Boulevard, Kiev 252004, USSR

The experimental study was conducted out on rats with an aim to work out the scientifically substantiated recommendations in relation to using the ultra-violet (UV) excimeric lasers in dermatology. Analyzed were the skin reactions to impacts of the UV-laser short impulses of different wavelengths ( $=308 \mathrm{~nm}, 248 \mathrm{~nm}, 222 \mathrm{~nm}$ ) and of different powers ( $E=I 0-40 \mathrm{~mJ})$. At that, the ablation of skin layers occurs with the formation of a defect the shape and size of which is close to the irradiated spot. It was established that the thickness of epidermal layer removed is dependent upon wavelength, power density and the number of impulses.

It was demonstrated, both visually and by means of microscopy, that the exposure to short, powerful UV-laser impulses results in vaporization of tissue with the formation of epidermal defect having the even, smooth margins without any apparent thermal coagulation. At that, there were noted histologically the minimal phenomena of coagulational necrosis of tissue and protein denaturation which indicate the perspectivity of using the excimeric UV-laser in dermatology and cosmetolog 7 . 